\title{
Economic Well-Being of Selected Administrative Staff of an Urban Public University: A qualitative study
}

\author{
Nor Hafizah Mohamed Harith $1^{*}$, Hazizan Md. Noon ${ }^{2}$ \\ 1 Universiti Teknologi MARA, Shah Alam, 40000, Malaysia \\ 2 International Islamic University Malaysia, Kuala Lumpur,53100, Malaysia
}

\begin{abstract}
The trend of urbanization in Malaysia is increasing and presently sixty-seven percent (67\%) of the Malaysia's population are living in the urban regions. Therefore, the concern over the quality of life of the urban residents becomes more crucial in the Malaysian government's policy. It can be predicted that the urban population will face greater obstacles in availing the opportunities and coping with the challenges of living in the cities. In this regards, the economic well-being of the urban population is the central aspect affecting their subjective well-being (SWB). Hence, this research aims to explore how the economic well-being affects the subjective well-being (SWB) among the selected respondents who live in the major cities in the Klang Valley, Malaysia. Adopting the Allard's dimensions of welfare, this study explores the subjective meaning of life satisfaction among the administrative personnel of an urban public university, namely Universiti Teknologi MARA (UiTM). Sixteen key informants from four different categories of administrative staff of the University's main campus in Shah Alam, Selangor were engaged in the researchers' in-depth interviews. The main findings of this research have shown that the responses were centred on the coping ability adopted by the UiTM administrative staff to survive life in the urban areas.

(C) 2016. The Authors. Published for AMER ABRA by e-International Publishing House, Ltd., UK. Peer-review under responsibility of AMER (Association of Malaysian Environment-Behaviour Researchers), ABRA (Association of Behavioural Researchers on Asians) and cE-Bs (Centre for Environment-Behaviour Studies, Faculty of Architecture, Planning \& Surveying, Universiti Teknologi MARA, Malaysia.
\end{abstract}

Keywords: Economic Well-Being; Subjective Well-Being ; UiTM Administrative Staff;Malaysian Quality of Life (MQLI)

\section{Introduction}

Urban communities in Malaysia have experienced the impact of economic development since its independence in 1957. At present, the trend of urbanization is increasing with sixty-seven \% of the Malaysian population living in the cities. Hence, one could predict that the urban population will face greater challenges in adjusting their life to the opportunities and difficulties of living in the cities. Therefore, the concern over the quality of life of the urban residents becomes more crucial in Malaysia government's policy (Tenth Malaysia Plan 2010-2015).The primary emphasis of Malaysia's urban development plan is to enhance the well-being of the urban population. For instance, the Malaysian Quality of Life (MQLI) was developed by the

\footnotetext{
${ }^{*}$ Corresponding author. Tel.: +0-000-000-0000

E-mail address: author@institute.xxx
} 
Economic Planning Unit (EPU) of the Prime Minister's Department in 1999 to measure the nation's quality of life. However, the question is to what extent does the economic well-being affect the Subjective Well-Being (SWB) of people who live in the cities. Therefore, the primary aim of this study was to examine how the economic well being affects the SWB among the selected respondents who live in the major cities in the Klang Valley, Malaysia.

\section{Literature Review}

Economic progress and affluence are the primary focus of many economic policymakers today. Many economists believed that money buys happiness, and it thus follows that income is the sole measure of the people's well-being (KrishanDutt and Radcliff, 2009). Economists typically equate economic development with per capita income or product, and they usually measure inequality and poverty in terms of real income or consumptions. However, in the early 1970s, Easterlin found that happiness, from the perspective of (SWB), does not seem to rise systematically with income (Easterlin and Sawangfa, 2009). Indeed, this finding appears to be in contradiction with the prevailing underlying assumption of many economists (KrishanDutt and Radcliff, 2009). For instance, previous studies have found that there is a weak relationship between income and well-being (see Boes and Winkelman, 2010). However, KrishanDutt and Radcliff (2009) argue that across countries, most studies have found that beyond a certain level of income, happiness does not rise significantly with the increment in earnings. This phenomenon has been referred to as the Easterlin Paradox (Krishna Dutt and Radcliff, 2009).

Since money is one of the most talked about and hotly debated issues in the annals of happiness, the central question is, can money buy happiness? Diener \& Biswas-Diener (2008) argued that money is related to SWB in extremely complex ways. He postulated that it is likely that income is related to happiness in part because people with high SWB are more liable to make high levels of income. He argued that much of the data did not indicate the causal influence of money on people's well-being. For instance, previous researchers have shown that people with little money experience higher well-being (Diener \& Biswas-Diener, 2008). Indeed, they say that money cannot fulfil certain human needs, and in fact he has made a reservation that money matters little or not at all for happiness.

Previous studies have proven that revenues and economic factors are important for life satisfaction (Easterlin, 1974; Boes \& Winkelman, 2010; Rojas, 2007, 2008, 2009; Christoph, 2001; Bonini, 2008; Y.K. Chan \&Rance PL Lee,2006). Indeed, the economic factors have proven to be more significant among the low socio-economic status segments of society (Daraei \& Mohajery, 2012). Their study showed that SWB in developing countries might be relevant due to the narrow focus on GDP in measuring the quality of life.

Paradoxically some earlier research also denied the relationship between the two, happiness and income, in the long- term, claiming that happiness declines as income rises (Easterlin, 1995). Therefore, this indicates that the material domain is not a reliable predictor of life satisfaction even though for some countries and cultures, the social class and economic factors are the critical areas that determine life satisfaction. It had been proven in a study carried out by Chau-Kiau Cheung and Kwan-Kwok Leung in 2004. Their study found that income and economic conditions are more relevant to life satisfaction among people in the lower income bracket, as compared to those in the higher income class. Other than that, the findings also showed that social class is very relevant to Chinese people's life satisfaction. Hence, this study demonstrated that people of different social strata develop their perception of life satisfaction differently. Unlike the West, class is very much relevant to Chinese people's perception of life satisfaction.

Interestingly, in the context of social class, Diener \& Biswas-Diener (2002) found that gaining more income is directly related to life satisfaction if someone belongs to the middle class or upper class. Furthermore, acquiring more money is unlikely to increase SWB on a long-term basis. They suggested that people should understand that placing greater emphasis on the acquisition of wealth has its associated dangers as well as pleasure. Therefore, a new paradigm is needed in which greater emphasis is placed on prevention of involuntary poverty, which is associated with a higher risk of unhappiness (Diener \& BiswasDiener, 2002: 31).

In light of the above, Diener \& Biswas-Diener (2008) highlighted the important lesson regarding the paradox that money means a lot more than purchasing power. They found that money meant social status, feeling of control, and enjoyable work. However, materialism can be toxic to happiness as too much work can interfere with other areas of one's life, such as family. Although money and happiness are often linked, the effect of money on happiness is often not large. In short, it can be concluded that it is our material aspirations that affect our mood and expectations. The researchers thus argued that materialists are less satisfied with their lives than those who highly value love, friendships, and other worthwhile pursuits. In other words, 
money has its role to play in creating happiness when perceived and managed appropriately, but it can turn out to be detrimental to one's happiness when it is treated otherwise. Hence, too much or too little money can produce any of these two consequences due to the way people perceive and treat it.

In a nutshell, the relationship between income and SWB are intriguing. In fact, Diener \& Biswas-Diener (2002) have emphasized the need for better measures and hence more probing research. Therefore, a qualitative or in-depth research is required to probe further into the extent of the importance of economic well-being on the respondents' subjective life satisfaction.

\section{Conceptual Framework}

Allard's basic needs approach whose structure combines both the objective and subjective indicators were utilized. Allard's needs approach consists of three basic needs that are related to three fundamental human needs both materials and nonmaterials that are essential to gauge more holistically the actual level of welfare in a society. The three elements are known as 'having', 'loving' and 'being' needs (Allardt, 1993). Allardt (1993) highlighted the importance of a richer and more inclusive theoretical approach to quality of life, based on objective measures of external conditions and subjective evaluation of people's quality of life.

The 'having' needs refers to those material conditions that are necessary for survival and the avoidance of misery. In the Scandinavian countries, the material conditions are measured by the domains that are related to material conditions necessary for survival and avoidance of the problem. The issues deal with the economic resource, housing conditions, employment, working conditions, health, and education. On the other hand, the 'loving' needs are defined as requirements related to other people and are necessary to form social identities. Examples include attachments in their local community, friendship and relationship with co-workers. Finally, the 'being' needs is defined as the need for integration of society and to live in harmony with nature. Examples include participation in political activities, indulging in leisure activities and doing meaningful work.

\section{Research Methodology}

\subsection{Research design}

In this qualitative study, a case study research design was preferred due to several reasons. A case study is a form of research inquiry that involves the study of a phenomenon explored through one or more cases within a bounded system (Miles and Huberman, 1994; Punch, 2005; Creswell, 2009; Merriam, 2009; Stake, 2010 \& Yin, 2009). This method was preferred given the fact that studies on economic well-being have been mostly quantitative in nature without much insight into the subjects' sophisticated understanding and experience of well-being. This research has adopted a single case approach with embedded multiple units of analysis to represent a typical case. The primary objective is to capture the circumstances and conditions of the commonplace situation facing the subjects of the study.

\subsection{Participants}

A total of 16 participants were selected on voluntary basis from the respective four categories representing four - grade schemes of the civil servants. The subjects were drawn from the population whose age was above 18 years old and are married. Four subjects: two males and two females were selected from each grade category. A type of purposeful sampling technique was employed in the selection of the respondents of the study. This method allows researchers to identify the widest possible range of the participants' characteristics that suits the study interests.

\subsection{Data collection}

Two techniques of data collection were employed to provide evidence for the study. First, an in-depth interview, which was the principal method of data collection. The second was a written feedback validation. Both techniques were chosen to enable the researcher to triangulate the evidence to ensure the accuracy and to confirm the data (Stake,2010).Finally, to ensure internal validity and credibility of the research data, member check was performed. The process involved taking the preliminary findings or the tentative interpretations back to the respondents and asking them to verify their accuracy. 


\subsection{Data analysis}

A thematic analysis used by King \& Horrocks (2010) was employed to analyse the data. The data analysis involved three stages. The first phase involved descriptive coding, second stage; interpretative coding, and the last step is overarching themes. The analysis was built on the theoretical ideas or applied concerns that may underlie the study. The themes emerged by comparing the similarities and differences between the cases. The analysis was guided by the central research questions (King \& Horrocks, 2010) to capture its meaning. In assisting the process of data management, computer-aided software known as NVivo version 9 was employed to ensure rigorous data analysis.

\section{Findings}

The main findings of the study revealed that majority of the respondents were satisfied with their economic well being and this contributed to their SWB. The results showed that the most meaningful experience among all the sixteen respondents was centred on a central theme, that is the coping ability adopted by the respondents to sustain their lives in the city. The five subthemes that emerged from the theme were: 1) being thrifty, 2) being free from financial burden, 3) maintaining simple lifestyle 4) being blessed with "rezeki" (bounty) and 5) having a good financial planning. A summary of the main findings is shown in the table below:

Table 1. Summary of main theme and sub-themes

\begin{tabular}{lll}
\hline MQLI & Main Theme & Sub-Themes \\
\hline Income & Coping Ability & Being thrifty \\
\hline & Being free from financial burden \\
\hline & Maintaining simple life styles \\
\hline & Being blessed with "rezeki" ( bounty) \\
\hline & Having good financial planning \\
\hline
\end{tabular}

\section{Discussion}

The findings have shown that the economic well- being of the respondents were revolved around how they sustained and survived in a high-cost living environment. The findings of this study were similar to the study of life satisfaction among the Chinese urban residents that found that the residents living in a society with dramatic change, competition and increasing inequalities would experience such difficulties (Wang and VanderWeele, 2011). This study shows that the middle and lower grade salary of the civil servants living in the city had somehow affected their economic well - being. According to Norhaslina (2009), the plight of the town folks especially in Kuala Lumpur have been threatened by the rising cost of living and this has resulted in the increase of the urban poor. From this, it can be understood that urban life remains a challenge for the participants of this study to make a living in this modern time. The above findings can also be discussed in the light of Maslow's theory of need (1970). This theory says that before one could satisfy the higher level of life needs, one must gratify the lower level of human needs. In other words, if the basic needs were not fulfilled, an individual would work hard to fulfil them. Oishi, Diener, Lucas \& Suh (1999) have adopted the Maslow's theory in their study and found that financial satisfaction is more strongly associated with life satisfaction in poorer countries. Hence, satisfying lower level needs like income and housing is necessary as these are naturally very basic for life in poorer nations. As far as the findings of this study are concerned, the slight difference of experience and perception of the economic and financial necessity among respondents of different salary grades or scales does demonstrate similarity to this theory.Regarding social class, economic stability is often considered as a critical enhancer of human life satisfaction (Tsai, 2009). This is especially true for the urbanites that depend solely on the income generated from employment or businesses. Tsai (2009) reports that national wealth and economic growth are important domains for explaining 
why some people are happier and more satisfied than the others. In the context of this study, it was discovered that price instability has significantly challenged the state of happiness among the urban population.

As reported, this study has also revealed the coping abilities of the respondents in facing life challenges. Most respondents did admit that financial difficulties present a challenge to their urban life. Most of the respondents had adopted various strategies to cope with these challenges which include being thrifty, being able to maintain a moderate lifestyle, being free from unnecessary financial commitment, being grateful with the 'rezeki' and having sound financial planning. From the reported findings, a conclusion that can be made is that living in the city is more manageable for the respondents of higher position. On the other hand; life is very challenging for the respondents of a lower position.

Despite that, the study has shed some light on the coping strategies adopted by all respondents in the face of the higher cost of living. The findings can be understood in the light of Lazarus and Folkman's (1984) coping strategies. Lazarus and Folkman (1984) have classified two general forms of coping: emotion-focused and problem - focused that are used by most people to react to stressful conditions. Emotional coping is most likely to occur when an appraisal has been made, that nothing can be done to modify the harmful or challenging conditions. On the other hand, the problem-focused coping functions to change the stressors by direct action. It involves problem-focused strategies that include new skills, finding alternative channels of gratification, and developing new standards of behaviour.

In the context of this study, it has been observed that most respondents had adopted the problem-focused strategy by adopting alternative lifestyles to sustain life in the city. Nevertheless, this study also shows that the lower, middle income and young administrative staff had taken other initiatives to fulfil their material needs including taking extra jobs or migrating to other cities with lower cost of living in order to gain more income. Nevertheless, the emotional coping was pertinent to lower grade administrative staff that had demonstrated that, by being content with the present status, i.e. as a civil servant itself, is already a blessing for them. Despite the said measures, the rising cost of living has put pressure on these groups and challenged their coping ability to sustain their lives in the city.

\section{Recommendations}

Based on the above findings, several suggestions are proposed to promote greater economic well-being among the urban administrative staff especially in the light of particular insights on various aspects generated from the respondents' life experiences. Hence, to address the rising cost of living especially among the lower and middle-income groups, the wage of the urban administrative staff needs to be reviewed. Fulfilling the basic needs such as basic amenities expenses, food and housing seems to be more burdensome to the lower and middle-level administrative staff who have to resort to taking loans as a way out. On this issue, it may be noted that the National Budget 2013 seems to have partially addressed this concern; which might be a temporary measure in addressing the people's financial burden. For long-term sustainability, it is suggested that the Government continuously review the urban civil servants' salary schemes that can proportionately address the rising costs in the cities. Hence, it is recommended that the Government frequently review the cost of living allowances or COLA according to the state and district, so that it will be more realistic to commensurate with the high living costs in different cities like Kuala Lumpur and Shah Alam.

\section{Conclusion}

In conclusion, this case study has revealed that the economic well - being among the selected administrative personnel of Universiti Technology MARA is good, due to their coping ability to sustain a living in the urban area. The study shows that by being able to resort to various coping abilities have resulted in the respondents being satisfied with their subjective well-being. Since the study's samples are done only among a selected UiTM administrative staff, it is not representative of the entire staff. Hence, it is suggested that a larger scale of study be carried out to explore the investigated issue more comprehensively.

\section{References}

Allardt, E. (1993). Having, Loving, And Being: An Alternative to the Swedish Model of Welfare Research. In Martha. Nussbaum, Amartya. Sen (Ed.).The Quality of Life.Oxford: Clarendon Press. 
Boes, S \&Winkelman (2010).The Effect of Income on General Life Satisfaction and Dissatisfaction.Social Indicators Research,95, 111-128.

Bonini, A. (2008). Cross-National Variation in Individual Life Satisfaction: Effects of National Wealth, Human Development, and Environmental Conditions. Social Indicators Research,87(2), 223-236.

Christoph, B.(2010). The relation Between Life Satisfaction and the Material Situation: A Re-evaluation Using Alternative Measures. Social Indicators Research,98,475-499.

Creswell, J.W (2009). Research Design: Qualitative, Quantitative, And Mixed Methods Approaches (3rd Ed). Los Angeles: Sage Publications.

Daraei, M. \&Mohajery,A.(2012).The Impact of Socioeconomic Status on Life Satisfaction. Social Indicators Research, Published Online 10 April, 2012.

Diener, E. \&Biswar-Diener, R. (2008). Happiness: Unlocking the Mysteries of Psychological Wealth. USA: Blackwell Publishing.

Diener, E. \&Suh (1997). Measuring Quality of Life: Economic, Social and Subjective Indicators. Social Indicators Research, 40, $189-216$.

Diener. E. \&Biswas-Diener, R.( 2002). Will Money Increase Subjective Well-Being? A Literature Review and Guide to Needed Research. Social Indicators Research57, 119-169, Netherlands: Kluwer Academic Publishers.

Easterlin, R.A (1974). Does Economic Growth Improve the Human Lot? Some empirical Evidence. In Paul A. David and Melvin W. Reder, eds., Nations and Households in Economic Growth: Essays in Honor of Moses Abramovitz, New York: Academic Press.

Easterlin, R.A \&Sawangfa, O. (2009). Happiness And Domain Satisfaction: New Directions For The Economics Of Happiness. In KrishanDutt, A. and Radcliff, B. Happiness, Economics and Politics: Towards a Multi-Disciplinary Approach. UK: Edward Elgar.

Easterlin, Richard A (1995), "Will Raising the Income of all Increase the happiness of all? ", Journal of Economic Behavior and Organization, Vol. $27,35-48$.

King, N. \&Horrocks, C.(2010).Interviews in Qualitative Research. London: Sage Publications.

KrishanDutt, A. and Radcliff, B.(2009). Introduction: Happiness, Economics and Politics. InKrishanDutt, A. and Radcliff, B. Happiness, Economics and Politics: Towards a Multi-Disciplinary Approach. Edward Elgar Publishing Limited.

Lazarus, R.S. \&Folkman, S. (1984). Stress, Appraisal and Coping. Retrieved 25 October, 2012. http://books.google.com.my/books.accesseed on 25 October 2012.

Maslow, A.H. (1970). Motivation and Personality (2ndedn.). New York: Harper and Row.

Merriam, Sharan B. (2009), Qualitative Research: A Guide to Design and Implementation( 2nd ed.), USA: John Wiley \& Sons.

Miles, M. B. \&Huberman, A. M. (1994). An Expanded Sourcebook: Qualitative Data Analysis ( 2ndedn.). USA: Sage Publications.

Norhaslina Hassan (2009).Urbanization and Growth of Cities in Malaysia. (In edited Abdul RazakBaginda. Malaysia at 50 \& Beyond. Kuala Lumpur: Malaysian Strategic Research Centre.

Oishi,S., Diener, E.F.,Lucas, R.E. \& Suh, E.M.(1999). Cross-Cultural Variations in Predictors of Life Satisfaction: Perspectives from Needs and Values. Personality Social Psychology Bulletin, 25, 980-990.

Punch, K. F. (2005) Introduction to Social Research: Quantitative and Qualitative Approached(2ndedn.). London: SAGE Publications.

Rojas, M. (2007). A Subjective Well-Being Equivalence Scale for Mexico: Estimation and Poverty and Income- Distribution Implications. Oxford Development Studies,35(3), 273-293.

Rojas, M. (2008). Experienced Poverty and Income Poverty in Mexico: A Subjective Well-Being Approach. World Development,36(6), 1078-1093.

Rojas, M.(2009). Enhancing Poverty-Abatement Programs: A Subjective Well-Being Contribution. Applied Research Quality Life, 4, $179-199$.

Stake, R. E. (2010). Qualitative Research: Studying How Things Work. New York: The Guildford Press.

Tsai, M.C (2009).The Impact of Instability on Subjective Well-Being: A Cross-National Study in V. Moller and D. Huschka (eds). Quality of Life and the Millennium Challenge.

Wang, P.\&VanderWeele, T. J. (2011). Empirical Research on Factors Related to the Subjective Well-Being of Chinese Urban Residents.Social Indicators Research, 101, 447-459.

Y.K. Chan \&Rance P.L. Lee (2006).Network Size, Social Support and Happiness in Later Life: A Comparative Study of Beijing and Hong Kong. Journal of Happiness Studies, Vol 7, No.1, 87-112.

Yin, R.K. (2009).Case Study research: Design and Methods( 4thedn.). USA: SAGE Publications

Tenth Malaysia Plan 2011-2015. Retrieved August 26, 2010. http://www.epu.gov.my

(http://www.utusan.com.my retrieved 23/03/2012). 